Literature Research

\title{
KESEHATAN MENTAL IBU HAMIL SEBAGAI DAMPAK PANDEMI COVID-19
}

\author{
Abd. Rahman, Siti Urbayatun \\ Prodi S2 Psikologi Sains, Fakultas Psikologi, Universitas Ahmad Dahlan, Indonesia
}

\section{Email Corresponding: manmadragi_kia2007@yahoo.co.id}

Page : $59-67$

\section{Kata Kunci :}

Kesehatan Mental, Ibu Hamil

\section{Keywords:}

Mental Health,

Pregnant Women

\begin{abstract}
ABSTRAK
Penyebaran penyakit covid-19 merupakan ancaman signifikan bagi kesehatan mental ibu hamil. Dalam beberapa studi ibu hamil mengalami peningkatan gangguan kesehatan mental selama pandemi. Penelitian sebelumnya enemukan bahwa sebagian besar ibu hamil melaporkan gejala psikologis sedang sampai berat (kecemasan, stress dan depresi). Beberapa hal yang berkaitan dengan meningkatnya faktor risiko kecemasan dan depresi selama pandemi covid-19, disebabkan oleh kehamilan primipara, wanita hamil pada usia muda, pendapatan yang rendah, status pekerjaan. Metode : Tinjauan literatur dengan pencarian beberapa jurnal sesuai dengan kriteria seleksi melalui situs-situs jurnal seperti Sciencedirect, Springerlink, Cambridge, Oxford jurnal, dan Proquest dengan memasukan kata kunci : "mental health AND women pregnancy", "depression AND women pregnancy AND pandemic COVID-19", pregnancy AND mental health", "effect pandemic COVID-19 AND women pregnancy". Hasil : Total artikel yang digunakan untuk dianalisa sejumlah 37 artikel yang memenuhi kriteria seleksi. Kesimpulan : Hasil temuan literatur terhadap dampak pandemi dimana sebagian besar di setiap negara terjadi peningkatan kecemasan, stress dan depresi pada ibu hamil. Status pekerjaan, beban ekonomi dan dukungan sosial yang kurang menjadi faktor yang mempengaruhi terjadinya masalah kesehatan mental.
\end{abstract}

\section{ABSTRACT}

Background: Spread of covid-19 is significant threat to mental health of pregnant women. In several studies pregnant women experienced an increase in mental health disorders during the pandemic. Previous studies have found that most pregnant women report moderate to severe psychological symptoms (anxiety, stress and depression). Several things related to the increased risk factors for anxiety and depression during the COVID-19 pandemic, are caused by primiparous pregnancy, pregnant women at a young age, low income, employment status. Methods: Literature review by searching several journals according to selection criteria through journal sites such as Scienceirect, Springerlink, Cambridge, Oxford journals, and Proquest by entering keywords: "mental health AND women pregnancy", "depression AND women pregnancy AND pandemic COVID -19 ", pregnancy AND mental health", "effect pandemic COVID-19 AND women pregnancy". Results: The total number of articles used for analysis was 37 articles that met the selection criteria. Conclusion: The findings of the literature on the impact of the pandemic where in most countries there is an increase in anxiety, stress and depression in pregnant women. Work status, economic burden and lack of social support are factors that influence mental health problems. 


\section{PENDAHULUAN}

Pandemi COVID-19 merupakan pandemi terburuk yang terjadi di abad 21. Penularan yang cepat, terjadinya kematian yang tidak terduga, ketidakjelasan model penularannya menjadi momok menakutkan dan menimbulkan kecemasan pada masyarakat ${ }^{1}$. Saat ini, hanya ada sedikit informasi tentang perubahan jangka panjang status kesehatan mental selama pandemi COVID-19 2 . Penelitian sebelumnya menemukan bahwa lebih dari separuh responden melaporkan gejala psikologis sedang sampai berat (kecemasan, depresi dan stres) ${ }^{3}$. Individu yang rentan stres akibat pandemi COVID-19 adalah ibu hamil dan ibu yang baru saja melahirkan ${ }^{4}$. Secara umum, sekitar $10-20 \%$ ibu menderita masalah kesehatan mental selama periode kehamilan dan perinatal (National Institute untuk Health and Care Excellence, 2020).

Kehamilan adalah masa perubahan besar yang terjadi pada tubuh manusia berada di bawah tekanan fisiologis. Perubahan yang sedang berlangsung ini mengganggu fungsi normal tubuh. Perubahan mood juga terdeteksi selama kehamilan, seringkali disalah artikan sebagai perubahan hormonal, meskipun rentan terhadap gangguan kejiwaan seperti depresi dan kecemasan, yang meningkat mulai dari masa konsepsi sampai kelahiran (gestasi) ${ }^{5}$. Menurut WHO (2020) sebanyak 10\% ibu hamil di dunia melaporkan gangguan kesehatan mental dan depresi, Angka ini bahkan lebih tinggi di negara berkembang, mencapai $15,6 \%$.

Di Amerika Serikat penyebaran virus corona secara dramatis telah mempengaruhi ibu dalam pengalaman kehamilan, kelahiran, dan awal menjadi orang tua dan akses mereka ke pelayanan perinatal. Menurut penelitian Qiao (2020) menunjukkan bahwa ibu hamil memiliki risiko yang sama untuk tertular COVID-19 dan memiliki penyakit yang sebanding untuk populasi umum, tetapi penelitian masih berkembang, dan banyak yang belum terjawab pertanyaan tentang efek COVID-19 pada wanita subur dan bayi, seperti efek jangka panjang COVID-19 pada perkembangan janin, perkembangan bayi, dan kesehatan reproduksi. Belum diketahui apakah virus itu bisa ditularkan ke janin selama kehamilan atau ke bayi saat lahir dan menyusui ${ }^{6}$. Penelitian restrospektif pada $9 \mathrm{ibu}$ hamil tanpa penyakit menemukan 6 di antaranya terindikasi SARS-CoV-2 7 . Penelitian klinis terhadap 10 bayi yang lahir dari ibu dengan pneumonia 2019-nCoV melaporkan bahwa belum dapat dipastikan telah terjadi penularan dari ibu ke bayi, namun dapat diduga penularan Infeksi COVID-19 kemungkinan besar ditularkan ke bayi melalui transmisi plasenta atau saat melahirkan ${ }^{8}$. Untuk alasan ini, ibu hamil mungkin merasa khawatir tentang kemungkinan terjadinya infeksi untuk ditularkan ke janin sehingga mengalami kecemasan ${ }^{9}$.

Sekitar $13 \%$ sampai $21,7 \%$ ibu hamil masing-masing mengalami depresi dan kecemasan antenatal dan diantara wanita yang dirawat di rumah sakit karena risiko obstetri, angka depresi antenatal bisa mencapai 19\%, selain itu risiko tinggi kehamilan dapat meningkatkan risiko depresi dan kecemasan, dan ibu hamil yang menjalani rawat inap dapat memperburuk kondisi kecemasan dan depresinya ${ }^{10}$. Studi tentang wabah SARS pada tahun 2003 telah menunjukkan bahwa ibu hamil mengalami kecemasan dan kekhawatiran tingkat tinggi tentang keberadaannya yang bisa terinfeksi. Meskipun sejumlah besar waktu telah berlalu sejak merebaknya pandemi COVID-19, informasinya masih terbatas tentang kemungkinan efek virus pada kehamilan ibu dan penularannya dari ibu ke janin ${ }^{11}$. Selain semua efek yang tidak diketahui lainnya, kurangnya informasi seperti itu akan 
memperparah timbulnya risiko besar pada ibu hamil dalam hal depresi dan kecemasan ditengah pandemi COVID-19 ${ }^{12}$.

Penyebaran penyakit

covid-19

merupakan ancaman signifikan bagi kesehatan mental ibu hamil. Dalam studi multisenter yang menargetkan ibu hamil setelah wabah COVID-19, sebesar 29,6\% mengalami peningkatan gejala depresi dengan menggunakan pengukuran Edinburgh Postnatal Depresi Scale, sebelum penyebaran epidemi sepenuhnya. Gejala depresi juga dikaitkan dengan perilaku menyakiti diri sendiri ${ }^{13}$. Peningkatan gejala depresi yang diamati bisa jadi sebagian dikaitkan dengan aksentuasi dari beberapa sebelumnya yang menyebutkan faktor penentu depresi. Misalnya, banyak negara, seperti Brazil, China, dan Amerika Serikat, telah melaporkan peningkatan kekerasan pasangan intim pada saat karantina dirumah ${ }^{14}$.

Pandemi COVID-19 bagi ibu hamil juga menyebabkan perubahan prosedur terhadap akses perawatan maternitas ${ }^{15}$, yang bila digabungkan dengan yang lebih luas adalah kekhawatiran COVID-19 berpotensi berdampak pada timbulnya stress ibu hamil dan respons perilaku mereka ${ }^{16}$. Ada beberapa bukti yang muncul mendukung hal ini, dengan laporan bahwa ibu hamil selama pengalaman pandemi dapat meningkatkan kekhawatiran dan perasaan yang rentan terutama depresi dan kecemasan ${ }^{17}$. Penelitian terhadap ibu hamil di Kanada dilaporkan bahwa terjadi peningkatan gejala kejiwaan, termasuk kecemasan, depresi, gangguan stres pascatrauma, dan gejala disosiatif dalam sampel ibu hamil selama COVID-19, dibandingkan dengan sampel sebelum COVID-19 ${ }^{18}$. Temuan dari studi yang dilakukan di China juga menunjukkan peningkatan depresi dan kecemasan pada ibu hamil setelah pengumuman penetapan pandemi COVID-19 ${ }^{19}$.
Penelitian mengidentifikasi dua pandemi utama terkait domain stress untuk ibu hamil di AS, Polandia, Israel, dan Jerman: yaitu stress terkait dengan perasaan tidak siap untuk melahirkan karena Pandemi COVID-19 dan stres terkait dengan ketakutan akan COVID-19 terhadap infeksi perinatal. Kedua stress Kesiapsiagaan dan stress infeksi perinatal terkait pandemi memprediksi gejala kecemasan yang meningkat, bahkan setelah mengontrol gejala lainnya sebagai faktor prediktif ${ }^{20}$ Kehamilan dapat menjadi faktor risiko tambahan untuk munculnya tekanan psikologis, beberapa perkembangan gangguan psikopatologis dan meningkatnya keparahan selama pandemi.

Penelitian sebelumnya tentang COVID19 menunjukkan adanya signifikansi peningkatan tekanan psikologis pada ibu hamil ${ }^{21}$. Penelitian di Hongkong pada ibu hamil trimester satu, dua dan tiga sebesar 54\% mengalami kecemasan, $37 \%$ mengalami gejala depresi (Madhavanprabhakaran, et al. 2015). Beberapa hal yang berkaitan dengan meningkatnya faktor risiko depresi pada ibu hamil selama pandemi covid-19, disebabkan oleh kehamilan primipara, wanita hamil pada usia muda, pendapatan yang rendah, status pekerjaan ${ }^{13}$.

Tujuan dari penulisan literature review ini adalah untuk melihat perubahan dan gangguan psikologis ibu hamil dan faktor yang mempengaruhinya selama masa pandemi COVID-19 dari beberapa penelitian yang telah dilakukan dalam kondisi dan tempat/wilayah yang berbeda.

\section{METODE}

Penulis memperoleh artikel untuk penyusunan tinjauan literatur ini melalui beberapa tahapan. Penulis melakukan pencarian melalui situs-situs jurnal seperti Sciencedirect, Springerlink, Cambridge, Oxford jurnal, dan Proquest dengan 
memasukan kata kunci sebagai berikut : "mental health AND women pregnancy", "depression AND women pregnancy AND pandemic COVID-19", pregnancy AND mental health", "effect pandemic COVID-19 AND pregnancy" didapatkan 54 jurnal. Selanjutnya dilakukan analisa terhadap studi tersebut untuk semua literatur yang diidentifikasi dan mengeluarkan literatur yang tidak memenuhi kriteria seleksi. Kemudian menganalisis versi teks lengkap (full text) dan tidak menganalisis yang literature yang teksnya tidak lengkap dan jurnal yang terseleksi 37 jurnal/artikel. Membuat kesimpulan temuan tentang dampak pandemi secara psikologis pada ibu hamil serta faktorfaktor yang mempengaruhi. Tahapannya dapat dilihat pada gambar 1 berikut :

0

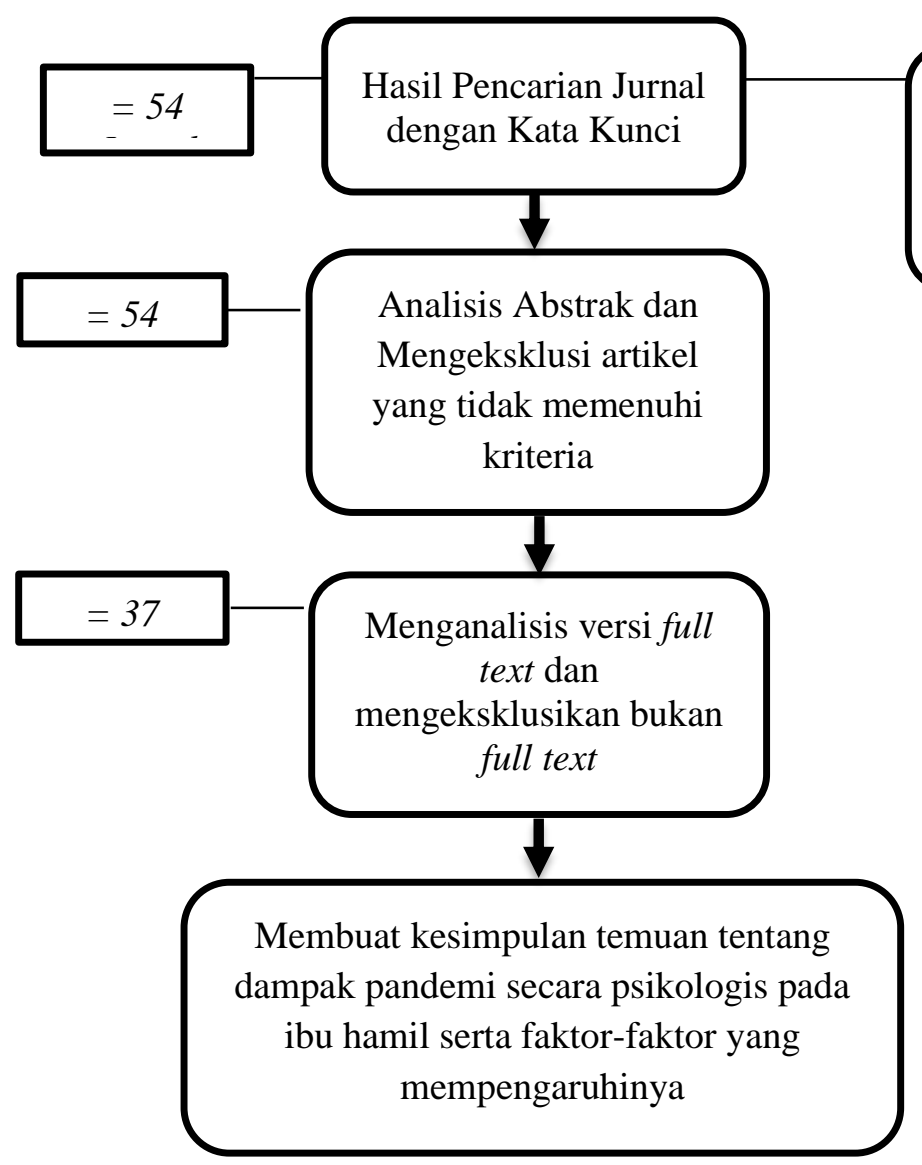

Gambar 1 : Diagram Alur Studi literatur 


\section{HASIL DAN PEMBAHASAN}

Hasil dan pembahasan berdasarkan tujuan penulisan literatur untuk melihat perubahan dan gangguan psikologis ibu hamil dan faktor yang mempengaruhinya selama masa pandemi COVID-19 dari beberapa penelitian yang telah dilakukan dalam kondisi dan tempat/wilayah yang berbeda. Ulasan ini mengeksplorasi status kesehatan mental dari ibu hamil dan faktor prediktifnya di tengah pandemi COVID-19.

Secara umum, prevalensi gejala gangguan psikiatri lebih tinggi pada ibu hamil jika dibandingkan dengan prevalensi sebelum pandemi (Huang et al., 2019). Variasi prevalensi semua penelitian memiliki perbedaan dari skala pengukuran, pola pelaporan differensial termasuk perbedaan budaya setiap negara, kondisi ekonomi, kesiapan pemerintah menghadapi pandemi, ketersediaan fasilitas kesehatan dan penyebaran informasi terkait COVID-19 secara tepat. Gangguan psikologis lebih sering terlihat pada awal wabah saat individu dihadapkan dengan karantina wajib, pengangguran tak terduga, dan ketidakpastian terkait dengan wabah (Ho et al., 2020).

Ibu hamil merupakan kelompok yang rentan mengalami gangguan psikologis selama kehamilannya, memiliki tingkat kecemasan dan depresi yang tinggi dalam menghadapi persalinan 22. Namun secara dramatis prevalensi kecemasan dan depresi meningkat pada saat terjadinya pandemi dibandingkan sebelum pandemi COVID-19 ${ }^{23}$. Tingginya kecemasan dan depresi pada ibu hamil disebabkan perberlakuan lockdown oleh pemerintah yang tentu saja membatasi ruang gerak mereka dan berdampak pada kesehatan mental terutama cemas dan depresi. Terbatasnya interaksi dengan anggota keluarga, teman-teman bahkan suaminya mempengaruhi suasana hati, hubungannya dengan pasangan, anggota keluarga dan teman-teman. $44 \%$ melaporkan suasana hati yang buruk karena kesepian merindukan kontak dengan teman dan keluarga ${ }^{24}$.

Selama lockdown ibu hamil juga mengalami gejala disregulasi suasana hati terutama pada mereka yang memiliki status sosial ekonomi rendah yang menyebabkan rentan terhadap gangguan mood prenatal ${ }^{25}$. Selain itu ibu hamil yang berusia lebih muda, berpenghasilan menengah kebawah, dan bekerja penuh waktu mempunyai peningkatan risiko mengembangkan gejala depresi selama pemberlakuan lockdown sehingga menyebabkan perilaku menyakiti diri sendiri 13. Sebanyak $82,5 \%$ ibu hamil melaporkan perubahan perilaku negatif dalam status kesehatan mental dimana mengalami stress, kecemasan dan perubahan pola tidur. Perilaku negatif ini terjadi akibat pandemi termasuk menurunnya aktivitas fisik atau meningkatnya perilaku tidak sehat bahkan terjadi peningkatan penggunaan alkohol secara signifikan ${ }^{26}$. Selama pandemi mereka mengalami kecemasan yang substansial seperti yang ditunjukkan oleh tingginya prevalensi kecemasan ringan, sedang, dan berat pada beberapa ibu hamil. Stress terkait dengan persiapan kelahiran selama pandemi, harapan ibu dan kekhawatiran tentang persalinan berubah secara signifikan. Bahkan dalam daerah di mana epidemi tidak terlalu meluas, wanita sangat khawatir tentang COVID-19 dan banyak lagi tentang kesehatan pasangan mereka dan kerabat mereka daripada kesehatan mereka sendiri, hal ini juga lebih dominan terjadi pada ibu hamil yang memiliki riwayat gangguan psikologis 27

Masa kehamilan memerlukan lingkungan nyaman yang dapat diakses oleh ibu sehingga bisa menjaga kondisi psikologisnya, dimasa pandemi aktifitas fisik ibu terganggu, rutinitas yang sering dijalankan menjadi terbatas bahkan terhenti, tidak adanya kumpul keluarga, teman, akses keluar rumah termasuk akses ke pelayanan kesehatan ibu dan anak makin menambah beban psikologis dan hal ini 
tidak hanya berdampak pada ibu, tetapi juga pada perkembangan janin dalam kandungan ${ }^{28}$. Peningkatan prevalensi kecemasan dan depresi selama pandemi pada ibu hamil akan berpotensi terjadinya persalinan prematur dan ketuban pecah dini dan ibu hamil dengan trombofilia yang terendah ${ }^{12}$. Sekitar $30 \%$ ibu hamil melaporkan mengalami stress kesiapsiagaan tinggi, stress infeksi perinatal yang tinggi yang dapat mengakibatkan perdarahan dan infeksi persalinan ${ }^{29}$.

Peningkatan stress pada ibu hamil juga berbeda setiap trimester kehamilan. Pada trimester pertama kehamilan peningkatan stres akibat pekerjaan dimana dengan adanya pandemi banyak yang bekerja dari rumah dan hal ini meningkatkan kekhawatiran ibu hamil trimester pertama dibandingkan trimester kedua dan ketiga. Di sisi lain, ibu hamil pada trimester kedua kehamilan lebih cenderung merasa tidak berdaya dibandingkan ibu hamil pada trimester pertama dan ketiga kehamilan 30.

Ketahanan fisik dan psikologis ibu hamil disetiap negara berbeda-beda, ibu hamil kulit hitam memiliki gejala kecemasan dan depresi yang lebih tinggi dibandingkan kulit putih. Kecemasan yang mereka alami adalah bagaimana melakukan perawatan prenatal selama pandemi termasuk ketidaktahuan akan pengalaman melahirkan dan pasca bersalin ${ }^{31}$. Selain itu di Israel, kehamilan dengan kecemasan yang tinggi juga terjadi pada wanita arab selama pandemi COVID-19 dibandingkan wanita yahudi ${ }^{9}$. Namun perlu diingat bahwa disamping gangguan psikologis, ibu hamil juga mempunyai risiko tinggi tertular COVID-19, karena memiliki akses terhadap perawatan prenatal, berhubungan dengan dokter dan bidan, fasilitas pelayanan kesehatan dan akses terhadap keluarga dan teman-teman. Di antara 9 ibu hamil dengan infeksi 2019-nCoV yang dikonfirmasi di RS China, didapatkan gejala klinis COVID-19 terjadi sebelum melahirkan 4 kasus, pada hari melahirkan 2 kasus, dan setelah melahirkan 3 kasus. ${ }^{7}$.

Kondisi pandemi COVID-19 menciptakan faktor risiko tambahan yang cenderung meningkatkan stres ibu hamil yang sudah rentan terhadap depresi dan kecemasan. Para wanita ini secara alami tidak hanya peduli dengan kesehatan mereka sendiri tetapi juga untuk bayi mereka yang belum lahir karena penyakit menular tersebut ${ }^{32}$. Terlepas dari tekanannya yang luar biasa, depresi selama kehamilan tetap diremehkan dan cenderung tidak terlihat di kalangan masyarakat di suatu negara. Selain itu, kesadaran dan pengetahuan masyarakat tentang kesehatan mental pada masa prenatal dan postnatal masih sangat kurang (Kingston et al., 2014).

\section{KESIMPULAN DAN SARAN}

Pandemi COVID-19 merupakan ancaman yang serius terhadap kesehatan mental ibu hamil, baik mulai diumumkannya status pandemi sampai dengan kondisi pandemi saat ini. Hasil temuan literatur terhadap dampak pandemi dimana sebagian besar di setiap negara terjadi peningkatan kecemasan, stress dan depresi pada ibu hamil. Status pekerjaan, beban ekonomi dan dukungan sosial yang kurang menjadi faktor yang mempengaruhi terjadinya masalah kesehatan mental. Kekhawatiran penularan COVID-19 baik pada ibu dan janinnya pada saat melakukan pemeriksaan antenatal, serta kurangnya pengalaman melahirkan dimasa pandemi makin memperparah kondisi tersebut. Selain itu ketahanan fisik dan psikologis juga dipengaruhi ras/etnis, termasuk ibu hamil yang memiliki risiko tinggi kehamilan akan mempengaruhi kesehatan mental ibu hamil dan pengaruhnya berbeda-beda pada ibu disetiap periode kehamilan (trimester kehamilan). Gangguan psikologis pada ibu hamil akan memberikan efek yang besar terhadap perawatan kehamilan, perkembangan 
janin dalam kandungan sampai dengan proses persalinan dan masa nifas.

Kebijakan dan intervensi kesehatan mental harus terus mempertimbangkan dan mengidentifikasi ibu hamil yang secara khusus rentan terhadap dampak kesehatan mental akibat pandemi. Upaya promotif dan preventif menjadi langkah yang tepat diantaranya meningkatkan efikasi diri dan memotivasi wanita untuk terlibat dalam kegiatan sehat yang dapat bermanfaat mengurangi kecemasan yaitu dengan melibatkan wanita secara langsung atau melalui telemedicine dan memberikan informasi tentang prosedur keamanan infeksi COVID-19 dalam rangka kehamilan, persalinan dan nifas, tindakan ini akan mengurangi stress dan kecemasan.

\section{UCAPAN TERIMAKASIH}

Terimakasih penulis ucapan kepada semua pihak yang telah membantu dalam penyelesaian penelitian ini.

\section{DAFTAR PUSTAKA}

1. Alshehri FS, Alatawi Y, Alghamdi BS, Alhifany AA, Alharbi A. Prevalence of post-traumatic stress disorder during the COVID-19 pandemic in Saudi Arabia. Saudi Pharm J. 2020;(xxxx). doi:10.1016/j.jsps.2020.10.013

2. López-Morales H, del Valle MV, CanetJuric L, et al. Mental health of pregnant women during the COVID-19 pandemic: A longitudinal study. Psychiatry Res. 2020;295.

doi:10.1016/j.psychres.2020.113567

3. Wang C, Pan R, Wan X, et al. Immediate Psychological Responses and Associated Factors during the Initial Stage of the 2019 Coronavirus Disease ( COVID-19) Epidemic among the General Population in China. Published online 2019.

4. Thapa SB, Mainali A, Schwank SE, Acharya G. Maternal Mental Health in the Time of the COVID-19 Pandemic.; 2020. doi:10.1111/aogs.13894

5. Coussons-read ME. Effects of prenatal stress on pregnancy and human development: mechanisms and pathways.
Obstet Med. 2013;(Figure 2):52-57.

6. Schwartz DA. An analysis of 38 pregnant women with COVID-19, their newborn infants, and maternal-fetal transmission of SARS-CoV-2: Maternal coronavirus infections and pregnancy outcomes. Arch Pathol Lab Med. 2020;144(7):799-805. doi:10.5858/arpa.2020-0901-SA

7. Chen H, Guo J, Wang C, et al. Clinical characteristics and intrauterine vertical transmission potential of COVID-19 infection in nine pregnant women: a retrospective review of medical records. Elsevier. Published online 2020:809-815. doi:10.1016/S0140-6736(20)30360-3

8. Zhu H, Wang L, Fang C, et al. Clinical analysis of 10 neonates born to mothers with 2019-nCoV pneumonia. Transl Pediatr. 2020;9(1):51-60. doi:10.21037/tp.2020.02.06

9. Ben-ari OT, Chasson M, Sharkia SA, Weiss E. Distress and anxiety associated with COVID-19 among Jewish and Arab pregnant women in Israel Distress and anxiety associated with COVID-19 among Jewish. J Reprod Infant Psychol. 2020;38(3):340-348.

doi:10.1080/02646838.2020.1786037

10. Littleton HL, Breitkopf CR, Berenson AB. Correlates of anxiety symptoms during pregnancy and association with perinatal outcomes: a meta-analysis. Am J Obstet Gynecol. 2007;196(5):424-432. doi:10.1016/j.ajog.2007.03.042

11. Rasmussen SA, Smulian JC, Lednicky JA, Wen TS, Jamieson DJ. Coronavirus Disease 2019 (COVID-19) and pregnancy: what obstetricians need to know. Am $J$ Obstet Gynecol. 2020;222(5):415-426. doi:10.1016/j.ajog.2020.02.017

12. Sinaci S, Ozden Tokalioglu E, Ocal D, et al. Does having a high-risk pregnancy influence anxiety level during the COVID-19 pandemic? Eur J Obstet Gynecol Reprod Biol. 2020;255:190-196. doi:10.1016/j.ejogrb.2020.10.055

13. Wu Y, Zhang C, Liu H, et al. Perinatal depressive and anxiety symptoms of pregnant women during the coronavirus disease 2019 outbreak in China. Am J Obstet Gynecol. 2020;223(2):240.e1- 
240.e9. doi:10.1016/j.ajog.2020.05.009

14. Peterman A, Potts A, Donnell MO, et al. COVID-19, Family Stress and Domestic Violence: Remote Work, Isolation and Bargaining Power. Cent Glob Dev. 2020;(13570):43.

15. Coxon K, Turienzo CF, Kweekel L, et al. The impact of the coronavirus (COVID19) pandemic on maternity care in Europe. Midwifery. 2020;88(January). doi:10.1016/j.midw.2020.102779

16. Matvienko-Sikar, S. Meedya CR. Perinatal mental health during the COVID-19 pandemic. Women and Birth. 2020;(January).

17. Yassa M, Birol P, Yirmibes C, et al. Nearterm pregnant women's attitude toward, concern about and knowledge of the COVID-19 pandemic. J Matern Neonatal Med. 2020;33(22):3827-3834. doi:10.1080/14767058.2020.1763947

18. Berthelot N, Lemieux R, GaronBissonnette J, Drouin-Maziade C, Martel É, Maziade M. Uptrend in distress and psychiatric symptomatology in pregnant women during the coronavirus disease 2019 pandemic. Acta Obstet Gynecol Scand. 2020;99(7):848-855. doi:10.1111/aogs.13925

19. Abedian Z, Soltani N, Mokhber N, Esmaily H. Depression and anxiety in pregnancy and postpartum in women with mild and severe preeclampsia. 2015;20(4):454-460. doi:10.4103/17359066.161013

20. Preis H, Mahaffey B, Heiselman C, Lobel M. Pandemic-related pregnancy stress and anxiety among women pregnant during the coronavirus disease 2019 pandemic. Am $J$ Obstet Gynecol MFM. 2020;2(3):100155. doi:10.1016/j.ajogmf.2020.100155

21. Lebel C, Anna MacKinnon, Mercedes Bagshawe, Lianne Tomfohr-Madsen, Giesbrech G. Pregnancy during COVID paper_04.23.2020 - Copy. 2020;(403).

22. Kalayil G, Sheila M, Souza D, Subrahmanya K. Prevalence of pregnancy anxiety and associated factors. 2015;3:17. doi:10.1016/j.ijans.2015.06.002

23. Cameron EE, Joyce KM, Delaquis CP,
Reynolds K, Protudjer JLP, Roos LE.

Maternal psychological distress \& mental health service use during the COVID-19 pandemic. $J$ Affect Disord. 2020;276(May):765-774. doi:10.1016/j.jad.2020.07.081

24. Milne SJ. Effects of isolation on mood and relationships in pregnant women during the covid-19 pandemic. Eur $J$ Obstet Gynecol Reprod Biol. 2020;252:610-611. doi:10.1016/j.ejogrb.2020.06.009

25. Silverman ME, Medeiros C, Burgos L. Early pregnancy mood before and during COVID-19 community restrictions among women of low socioeconomic status in New York City: a preliminary study. Arch Womens Ment Health. Published online 2020. doi:10.1007/s00737-020-01061-9

26. Ahlers-Schmidt CR, Hervey AM, Neil T, Kuhlmann S, Kuhlmann Z. Concerns of women regarding pregnancy and childbirth during the COVID-19 pandemic. Patient Educ Couns. 2020;103(12):2578-2582. doi:10.1016/j.pec.2020.09.031

27. Ravaldi C, Wilson A, Ricca V, Homer C, Vannacci A. Pregnant women voice their concerns and birth expectations during the COVID-19 pandemic in Italy. Women and Birth. 2020;(2019). doi:10.1016/j.wombi.2020.07.002

28. Fullana MA, Hidalgo-mazzei D, Vieta E, Radua J. Coping behaviors associated with decreased anxiety and depressive symptoms during the COVID-19 pandemic and lockdown. $J$ Affect Disord. 2020;275(April):80-81. doi:10.1016/j.jad.2020.06.027

29. Preis H, Mahaffey B, Heiselman C, Lobel M. Vulnerability and resilience to pandemic-related stress among $\mathrm{U} . \mathrm{S}$. women pregnant at the start of the COVID-19 pandemic. Soc Sci Med. 2020;266(August):113348. doi:10.1016/j.socscimed.2020.113348

30. Zhang Y, Ma ZF. Psychological responses and lifestyle changes among pregnant women with respect to the early stages of COVID-19 pandemic. Int $J$ Soc Psychiatry. Published online 2020. 
doi:10.1177/0020764020952116

31. Gur RE, White LK, Waller R, et al. The Disproportionate Burden of the COVID19 Pandemic Among Pregnant Black Women. Psychiatry Res. 2020;293(September):113475. doi:10.1016/j.psychres.2020.113475
32. Ayaz R, Hocaoğlu M, Günay T, Yardlmcl OD, Turgut A, Karateke A. Anxiety and depression symptoms in the same pregnant women before and during the COVID-19 pandemic. $J$ Perinat $\mathrm{Med}$. 2020;48(9):965-970. doi:10.1515/jpm2020-0380 